\title{
Effect of Streptomycin and GA3 Application on Seedlessness, Yield and Fruit Quality of 'Balady' Mandarin
}

\author{
A. R. El-Shereif *, A. E. Zaghloul ** and Doaa M. Abou Elyazid * \\ * Horticulture Department, Faculty of Agriculture, Kafrelsheikh University and** \\ Handling Research Department, Horticulture Research Institute, Agriculture \\ Research Centre, Egypt.
}

\begin{abstract}
T HE EFFECTIVENESS of repeated applications of GA3 and streptomycin (SM) to stimulate seedless fruit development or reducing seed number per fruit of mandarin (Citrus recticulata Blanco cv Balady) were evaluated under field conditions at Motobus district, Kafr El-Sheikh governorate during 2014 and 2015 seasons. Trees were sprayed with GA3 at $25 \mathrm{ppm}, \mathrm{SM}$ at $250 \mathrm{ppm}, \mathrm{SM}$ at $500 \mathrm{ppm}, \mathrm{SM}$ at $250 \mathrm{ppm}+\mathrm{GA} 3$ at $25 \mathrm{ppm}$ and $\mathrm{SM}$ at 500 ppm + GA3 at 25 ppm, while the control trees were sprayed with tap water. Results indicated that GA3 at $25 \mathrm{ppm}$ recorded the highest fruit weight and acidity in both seasons. SM $500+$ GA3 reduced seed number per fruit with about 76.66 and $77.46 \%$ reduction in both seasons, respectively compared to the control. Meanwhile, high yield and fruit characteristics, firmness, vitamin C, brix and SSC/Acid ratio, were maintained under this treatment. The addition of GA3 to SM increased its efficacy in this respect.
\end{abstract}

Keywords: Seedlessness, GA3, Streptomycin, Mandarin, Fruit quality.

\section{Introduction}

Citrus are one of the most widely cultivated and economically important fruit crops in the world and a major export product of Egypt. Mandarins represent around $25.35 \%$ of total Egyptian citrus production (Arab Agricultural Statistics Yearbook, 2011). Among the important cultivated varieties in Egypt is 'Balady' mandarin. The fruits of this variety have quite big number of seeds, which is disadvantage, since consumers prefer seedless fruit or that with less seed number.

Production of triploids by crossing is one of the most effective ways for producing seedless fruits (Grosser \& Chandler, 2004 and Reforgiato et al., 2005). However, desirable autotetraploid that can be used in such crosses are still limited. A citrus cultivar can be considered seedless if it is able to produce normal fruit containing no seeds, aborted seeds, or a significantly reduced number of seeds (Vardi et al., 2008).

Endogenous gibberellic acid levels increased in the parthenocarpic Fino Clementine, pear and grape cultivars (Coombe, 1960, Garcia-
Papi \& Garcia-Martinez, 1984 and Gil et al., 1972). Gibberellic acid (GA3) is widely used to induce seedlessness in seeded varieties in grapes (Fukunaga \& Kurooka, 1988, Ogasawara, 1985, Ogasawara and Hirata, 1985, Fellman et al., 1991, Shiba, 1980, Kazunori et al., 2001 and Cheng et al., 2013), cherry (Beppu et al., 2001 and 2005), loquat (Mesejo et al., 2010) and other fruits (Pharis and King, 1985).

Streptomycin (SM) is a human antibiotic drug which also is used as a pesticide, to control bacterial and fungal diseases of certain plants including fruit crops. The use of streptomycin to control fire blight on apples and pears accounts for $58 \%$ of its total use (U.S. Environmental Protection Agency. 1992). SM has been used to induce seedlessness in different grape varieties such as Kyoho (Fukunaga \& Kurooka, 1988, Ogasawara, 1985 and Shiba, 1980) and Muscat Bailey A (Ogasawara and Hitra, 1985).

GA3 failed to induce seedlessness in many cases (Motomura and Hori, 1978), thus cultivars need to be evaluated individually for this characteristic.

The objective of this study was to 
investigate whether GA3 and SM would be efficient in reducing seed number per fruit or producing seedless 'Balady' mandarin fruits.

\section{Materials and Methods}

The experiment was carried out at a private orchard located in Motobus area, Kafr El-Sheikh governorate, Egypt during 2014 and 2015 seasons. The experimental site is clay soil. Soil chemical and physical analysis is shown in Table 1 .

\section{Plant material and treatments}

Eighteen years old healthy and uniform mandarin (Citrus reticulata Blanco cv Balady) trees budded on sour orange and planted at 5 $\mathrm{m}$ apart were used in this study. Trees were subjected to six foliar spray treatments as follows:

- Control (tap water)

- GA3 at 25 ppm

- $\quad$ Streptomycin at $250 \mathrm{ppm}$

- Streptomycin at $500 \mathrm{ppm}$

- Streptomycin at $250 \mathrm{ppm}+\mathrm{GA} 3$ at $25 \mathrm{ppm}$

- $\quad$ Streptomycin at $500 \mathrm{ppm}+\mathrm{GA} 3$ at $25 \mathrm{ppm}$

Trees were sprayed three times, at the beginning of flowering, $50 \%$ of full bloom and at full bloom. Each treatment was represented with three trees.

TABLE 1. Some chemical and physical properties of the experimental soil.

\begin{tabular}{|c|c|c|c|c|c|c|c|c|c|c|c|}
\hline \multicolumn{3}{|c|}{ Physical } & \multicolumn{2}{|c|}{ Chemical } & \multicolumn{4}{|c|}{ Soluble Cations (meq..$^{-1}$ ) } & \multicolumn{3}{|c|}{ Soluble Anions (meq..$\left.^{-1}\right)$} \\
\hline Sand \% & $\begin{array}{l}\text { Silt } \\
\%\end{array}$ & Clay \% & pH & $\begin{array}{c}\text { Ec } \\
\left(\mathrm{dS} . \mathrm{m}^{-1}\right)\end{array}$ & $\mathbf{N a}+$ & $\mathbf{C a}++$ & Mg++ & $\mathbf{K}+$ & HCO3- & Cl- & SO4- \\
\hline 10.33 & 38.31 & 51.36 & 8.2 & 1.68 & 9.5 & 3.71 & 2.94 & 0.15 & 2.0 & 9.0 & 5.3 \\
\hline
\end{tabular}

Yield and fruit quality properties determination:

Fruits were harvested when SSC/acid ratio reached to $8-12$, then yield was calculated based on fruit number and average fruit weight per tree. Fruit physical and chemical properties were estimated. Fruit firmness was measured by using LFRA texture analyzer. Juice SSC was determined by a handy refractometer. Titratable acidity expressed as citric acid (\%) was estimated with titration with $\mathrm{NaOH}(0.01 \mathrm{~N})$ with presence of $\mathrm{Ph} \mathrm{Ph}$ indicator according to AOAC (1995), then SSC/acid ratio was calculated. Ascorbic acid content (V.C) was determined using 2, 6 dichlorophenol indophenol according to Jacobs (1951). Seed number per fruit was also counted using 100 fruit per replicate.
Statistical analysis

The experiment was laid out in a randomized complete block design with three replicates. Data were statically analyzed using CoStat 6.303, CoHort Software, 798 Lighthouse Ave. PMB 320, Monterey, CA, 93940, USA.

\section{$\underline{\text { Results }}$}

Data in Table 2 show that application of GA3 significantly increased fruit weight recording the highest values in both seasons followed by control and SM at $500 \mathrm{ppm}+\mathrm{GA} 3$ in the first season and both concentrations of SM+ GA3 in the second season with no significant difference. However, total fruit number and yield per tree was obtained at SM 500 ppm + GA3 in both seasons.

TABLE 2. Effect of $\mathrm{GA}_{3}$ and streptomycin (SM) application on fruit weight, fruit number per tree, yield and firmness in 'Balady' mandarin.

\begin{tabular}{lcccccccc}
\hline \multirow{2}{*}{ Treatments } & \multicolumn{2}{c}{ Fruit Weight (g) } & \multicolumn{2}{c}{ Fruit No./tree } & \multicolumn{2}{c}{ Yield (kg/tree) } & \multicolumn{2}{c}{$\begin{array}{c}\text { Fruit Firmness } \\
\text { g.mm }{ }^{-2}\end{array}$} \\
\cline { 2 - 10 } & $\mathbf{2 0 1 5}$ & $\mathbf{2 0 1 6}$ & $\mathbf{2 0 1 5}$ & $\mathbf{2 0 1 6}$ & $\mathbf{2 0 1 5}$ & $\mathbf{2 0 1 6}$ & $\mathbf{2 0 1 5}$ & $\mathbf{2 0 1 6}$ \\
\hline Control & $140.18 \mathrm{~b}$ & $138.93 \mathrm{~b}$ & $604.00 \mathrm{e}$ & $617.00 \mathrm{e}$ & $84.60 \mathrm{~d}$ & $85.73 \mathrm{c}$ & $31.40 \mathrm{e}$ & $34.38 \mathrm{e}$ \\
GA3 (25 ppm) & $146.94 \mathrm{a}$ & $150.73 \mathrm{a}$ & $615.00 \mathrm{~d}$ & $611.00 \mathrm{e}$ & $90.38 \mathrm{~b}$ & $92.09 \mathrm{~b}$ & $38.91 \mathrm{~d}$ & $40.02 \mathrm{~d}$ \\
SM (250 ppm) & $128.49 \mathrm{e}$ & $132.07 \mathrm{~d}$ & $674.67 \mathrm{~b}$ & $660.00 \mathrm{c}$ & $86.69 \mathrm{~cd}$ & $87.17 \mathrm{c}$ & $42.36 \mathrm{~cd}$ & $44.08 \mathrm{c}$ \\
SM (500 ppm) & $131.63 \mathrm{de}$ & $133.49 \mathrm{~cd}$ & $647.00 \mathrm{c}$ & $643.67 \mathrm{~d}$ & $85.16 \mathrm{~d}$ & $85.93 \mathrm{c}$ & $45.19 \mathrm{c}$ & $43.35 \mathrm{c}$ \\
SM (250)+GA3 (25) & $134.07 \mathrm{~cd}$ & $137.49 \mathrm{bc}$ & $671.67 \mathrm{~b}$ & $670.67 \mathrm{~b}$ & $89.88 \mathrm{bc}$ & $92.22 \mathrm{~b}$ & $53.85 \mathrm{~b}$ & $51.59 \mathrm{~b}$ \\
SM (500)+GA3(25) & $137.47 \mathrm{bc}$ & $138.32 \mathrm{bc}$ & $701.67 \mathrm{a}$ & $708.33 \mathrm{a}$ & $96.46 \mathrm{a}$ & $97.98 \mathrm{a}$ & $61.19 \mathrm{a}$ & $57.51 \mathrm{a}$ \\
\hline
\end{tabular}

Means followed by the same letter are not significantly different at $5 \%$ level by DMRT. 
A clear reduction in seed number per fruit was observed under all treatments compared to the control (Fig.1). The most effective treatment was SM $500+\mathrm{GA}_{3}$ with about 76.66 and 77.46 $\%$ reduction in both seasons, respectively. The addition of $\mathrm{GA}_{3}$ to $\mathrm{SM}$ increased its efficacy in this respect.

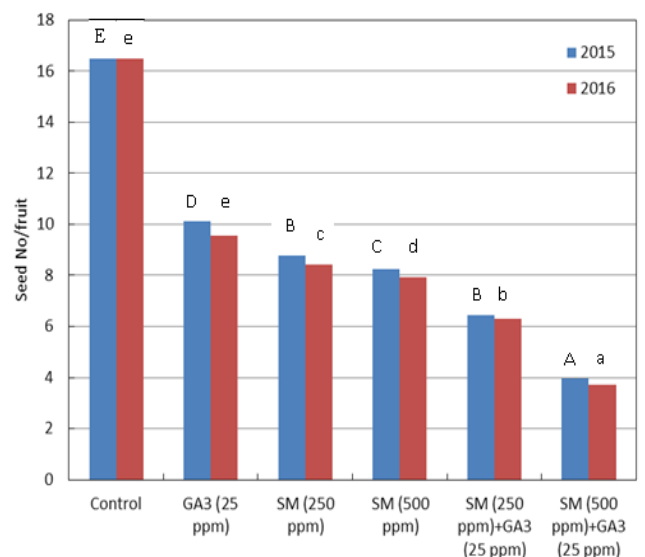

Fig.1. Effect of $\mathrm{GA}_{3}$ and streptomycin (SM) application on seed number per fruit in 'Balady' mandarin.

Fruit firmness was significantly higher in all treatments compared to control. $\mathrm{SM}+\mathrm{GA} 3$ treatments had the highest values followed by SM treatments alone, GA3 and control respectively.

Fruit chemical characters were improved by all treatments as compared to the control (Table 3). Soluble solids content (SCC) showed a significant increase recording the highest value at SM+GA3 with no significant difference between the two used concentrations in both seasons, while the lowest Brix value was found under control.

Titratable acidity of the juice increased as a result of GA3 application and reduced significantly at SM and $\mathrm{SM}+\mathrm{GA}_{3}$ treatments, consequently SSC/Acid ratio was increased with the highest ratio at $\mathrm{SM} 500+$ $\mathrm{GA}_{3}$ in the first season and both $\mathrm{SM}$ concentrations + GA3 in the second season. The lowest ratio recorded at control and $\mathrm{GA}_{3}$ alone treatments.

Vitamin $\mathrm{C}$ is one of the most important nutritional quality factors in many horticultural crops and has many biological activities in the human body. The content of vitamin $\mathrm{C}$ was enhanced as a result to SM treatments either alone or accompanied with $\mathrm{GA}_{3}$ compared to the control. The highest content was recorded at SM at 250 and $500 \mathrm{ppm}+\mathrm{GA}_{3}$ with no significant difference among these two treatments and the lowest content was found under control treatment, while the other treatments showed intermediate value of vitamin C.

\section{Discussion}

Among the major goals of improvement of fruit crops are large fruit size as well as reduced seed number and size (Varoquaux et al., 2000). Exogenous $\mathrm{GA}_{3}$ application is one of the strategies used to induce seedlessness in seeded grape varieties and so SM has been used for the same purpose (Fukunaga \& Kurooka, 1988, Ogasawara, 1985, Ogasawara \& Hirata, 1985 and Shiba, 1980).

GA3 application increased fruit weight significantly as compared to the control (Table 2). These findings are in agreement with the reports of Rokaya et al. (2016) and Pal et al. (1977) in mandarin, Singh et al. (2003) in pear, and Kaur et al. (2008) in plum. The increment in fruit weight may be due to hormone directed to transportation and accumulation of phytosynthates which resulted in better fruit development and also acceleration of cell division, elongation, and enlargement. Lu et al. (1997) found that seedless

TABLE 3. Effect of $\mathrm{GA}_{3}$ and streptomycin (SM) application on vitamin C content, SSC, acidity and SSC/Acid ratio of 'Balady' mandarin fruits.

\begin{tabular}{|c|c|c|c|c|c|c|c|c|}
\hline \multirow{2}{*}{ Treatments } & \multicolumn{2}{|c|}{$\begin{array}{c}\text { Vitamin C } \\
(\mathrm{mg} / 100 \mathrm{ml})\end{array}$} & \multicolumn{2}{|c|}{$\begin{array}{c}\text { SCC \% } \\
{ }^{\circ} \text { Brix } \\
\end{array}$} & \multicolumn{2}{|c|}{ Acidity \% } & \multicolumn{2}{|c|}{ SSC/Acid ratio } \\
\hline & 2015 & 2016 & 2015 & 2016 & 2015 & 2016 & 2015 & 2016 \\
\hline Control & $38.01 \mathrm{~d}$ & $37.63 \mathrm{~d}$ & $8.37 \mathrm{c}$ & $8.73 \mathrm{~d}$ & $0.96 \mathrm{~b}$ & $0.94 b$ & $8.75 \mathrm{~cd}$ & $9.33 \mathrm{~d}$ \\
\hline GA3 (25 ppm) & $39.18 \mathrm{~cd}$ & $39.77 \mathrm{c}$ & $8.40 \mathrm{c}$ & $8.80 \mathrm{~d}$ & $0.99 \mathrm{a}$ & $0.97 \mathrm{a}$ & $8.49 \mathrm{~d}$ & $9.21 \mathrm{~d}$ \\
\hline $\mathrm{SM}(250 \mathrm{ppm})$ & $40.21 b c$ & $39.88 \mathrm{c}$ & $8.40 \mathrm{c}$ & $9.43 \mathrm{c}$ & $0.91 \mathrm{c}$ & $0.91 \mathrm{c}$ & $9.26 \mathrm{c}$ & $10.37 \mathrm{c}$ \\
\hline $\mathrm{SM}(500 \mathrm{ppm})$ & $41.32 b$ & $41.10 \mathrm{~b}$ & $9.47 b$ & $9.73 b$ & $0.88 \mathrm{c}$ & $0.86 \mathrm{~d}$ & $11.01 \mathrm{~b}$ & $11.31 \mathrm{~b}$ \\
\hline $\mathrm{SM}(250)+\mathrm{GA} 3(25)$ & $42.91 \mathrm{a}$ & $43.53 \mathrm{a}$ & $9.80 \mathrm{a}$ & $10.57 \mathrm{a}$ & $0.85 \mathrm{~d}$ & $0.82 \mathrm{e}$ & $11.54 b$ & $12.98 \mathrm{a}$ \\
\hline $\mathrm{SM}(500)+\mathrm{GA} 3(25)$ & $43.45 \mathrm{a}$ & $44.26 \mathrm{a}$ & $10.07 \mathrm{a}$ & $10.73 \mathrm{a}$ & $0.82 \mathrm{~d}$ & $0.80 \mathrm{f}$ & $12.23 \mathrm{a}$ & $13.45 \mathrm{a}$ \\
\hline
\end{tabular}


berries in clusters of 'Triumph' grape treated with GA3 were characterized by smaller size. However, seeded berries under the same treatment weighed significantly more compared to nontreated vines.

Fruit firmness is one of the fruit quality characters. Fruit firmness was significantly higher in all treatments compared to control and it seems that the addition of GA3 to SM solution apparently increased fruit firmness (Table 2). These results are in conformity with the findings of Rokaya et al. (2016) and Ladaniya (1997) on mandarin and Abo El-Enien (2012) and Zahgloul (2004) on Navel orange, who stated that GA3 treated fruits had higher peel firmness.

The average number of seeds per fruit was significantly reduced as a result of either single or combined application of GA3 and SM (Fig.1). The combined treatment (SM at 500ppm+GA3 at $25 \mathrm{ppm}$ ) reduced seed number per fruit by about $77 \%$ with increased fruit yield compared to the control. Eshghi et al. (2010) found that streptomycin was effective in inducing seedlessness in the naturally seeded table grape 'Rotabi Seyah' with high total soluble solids and decreased bunch weight compared with control.

Application of GA3 before anthesis was found to accelerate embryo sacs degeneration after anthesis, whereas the GA-biosynthesis inhibitor, paclobutrazol (PBZ) increases their longevity (Beppu et al., 2001). Early degeneration of embryo sacs by GA3 treatments before anthesis also has been observed in 'Muscat Bailey A' (Takagi, 1980) and 'Kyoho' (Komatsu, 1987) grapes.

Mesejo et al. (2008) concluded that application ofGA3 the daysaroundanthesisimpairsfertilization by either enhancing ovule abortion or reducing pollen tube growth, in 'Clemenules' flowers under cross-pollination conditions. The intensity of the response depends on the physiological flower state at the moment of treatment.

The GA3 -induced increase in cell damage may be caused by reactive oxygen species, a decrease in antioxidant enzymatic activities, and an alteration of the expression of genes related to seed development (Cheng et al., 2013).

Concerning the induction of seedlessness by SM, Ogasawara (1985) suggested that principal action of SM should be to cause ovule abnormality and thus some different mechanism to cause seedlessness by GA based on the fact that SM carries sterilizing power against bacteria (inhibitory action of protein synthesis) and this may result in an inhibitory effect for ovary growth, cell division and enlargement in ovary wall tissue. Moreover, Fukunaga and Kurooka (1988) suggested that the increase in seedless berry set by addition of SM to GA solution would probably be due to the inhibitory effect of SM to seed growth and development.

\section{$\underline{\text { References }}$}

Abo El-Enien, M.M.(2012) Improvement of Washington navel orange fruits quality using water regimes, GA3, potassium and calcium foliar applications. Ph.D. thesis, Fac.Agri., Kafrelsheikh University, Egypt.

AOAC (1995) "Official Methods of Analysis", 16th ed., Association of Official Analytical Chemists, Washington DC.

Arab Agricultural Statistics Yearbook (2011) Vol. 31. http:// www.aoad. org/ eAASYXX.htm.

Beppu, K., Suehara, T. and Kataoka, I. (2001) Embryo sac development and fruit set of 'Satohnishiki' sweet cherry as affected by temperature, GA3 and paclobutrazol. J. Japan. Soc. Hort. Sci., 70, 157-162.

Beppu, K., Aida, K. and Kataoka, I. (2005) Increased endogenous gibberellin level induces early embryo sac degeneration of 'Satohnishiki' sweet cherry in a warm region. Acta Hortic., 667, 423-432. https://doi.org/10.17660/ActaHortic.2005.667.61

Cheng, C., Xu, X., Singer, S.D., Li, J., Zhang, H., Gao, M., Wang, L., Song, J. and Wang, X. (2013) Effect of GA3 treatment on seed development and seedrelated gene expression in grape. PLOS ONE, 8(11), 1-14. http://doi.org/10.1371/journal.pone. 0080044

Coombe, B.G. (1960) Relationship of growth and development to changes in sugars, auxin and gibberellins in fruit of seeded and seedless varieties of Vitis vinifera. Plant Physiol., 35, 241-250. http://dx.doi.org/10.1104/pp.35.2.241

Fellman, C., Hoover, E., Ascher, P.D., and Luby, J. (1991) Gibberellic acid-induced seedlessness in field-grown vines of 'Swenson Red' grape. Hort Science, 26 (7), 873-875

Eshghi, S., Kavoosi, B. and Farehi, M.H. (2010) Influence of streptomycin and cuso4 on seedlessness and fruit quality in 'Rotabi Seyah' table grape. Acta Hort. (ISHS) 884, 461-466 
Fukunaga, S and Kurooka, H. (1988) Studies on seedlessness of 'kyoho' grapes induced by gibberellin in combination with streptomycin. Bull. Univ. Osaka Pref. Ser. B., 40, 1-10.

Garcia-Papi, M.A. and Garcia-Martinez, J.L. (1984) Endogenous plant growth substances content in young fruits of seeded 'Clementine' mandarin as related to fruit set and development. Hort. Science, 22, 265-274.

Gil, G.F., Martin, G.C., and Griggs, W.H. (1972) Fruit set and development in the pear: Extractable endogenous hormones in parthenocarpic and seeded fruit. J. Amer. Soc. Hort. Sci., 97, 731-735.

Grosser, J.W. and Chandler, J.L. (2004) Production of twelve new allotetraploid somatic hybrid citrus breeding parents with emphasis on late maturity and cold-hardness. J. Am. Pomol. Soc., 58, 21-28.

Jacobs, M. B. (1951) "The Chemical Analysis of Foods and Food Products", pp. 724 - 732. D. Van. Nostrand, Inc. Now York, London.

Kazunori, I., Takahashi, H., Kato, H. and Ikeda, F. (2001) Effect of gibberellin spraying at full bloom on induction of improved cluster of seedless tetraploid grapes induced by streptomycin treatment. Jour. Agri. Sci. Tokyo Univ. Agric., 46 (3), 149-153.

Kaur, H., Singh, A., Gupta, M. and Randhawa, J.S. (2008) Effect of NAA and gibberellic acid on preharvest fruit drop and quality of Satluj purple plum. Haryana Journal of Horticultural Sciences, 37, 31-32.

Komatsu, H. (1987) Studies on poor-berry setting of 'Kyoho' grape. PhD thesis, Osaka Pref. Univ., Osaka.

Ladaniya, M.S. (1997) Response of Nagpur Mandarin Fruit to Preharvest Sprays of GA3 and Carbendazim. Indian Journal of Horticulture, 54, 205-212.

Lu, J., Lamikanra, O. and Leong, S. (1997) Induction of seedlessness in 'Triumph' Muscadine grape (Vitis rotundifolia Michx.) by applying gibbrellic acid. Hort Science, 32 (1), 89-90.

Mesejo, C., Martinez-Fuentes, A., Reig, C. and Agusti, M. (2008) Gibberellic acid impairs fertilization in Clementine mandarin under cross-pollination conditions. Plant Science, 175 (3), 267-271. DOI: 10.1016/j.plantsci. 2008.04.008.

Mesejo, C., Reig, C., Martínez-Fuentes, A., Agustí, M. (2010) Parthenocarpic fruit production in loquat (Eriobotrya japonica Lindl.) by using gibberellic acid. Scientia Horticulturae, 126 (1), 37-41.
Motomura, Y. and Hori, Y. (1978) Exogenous gibberellin as responsible for the seedless berry development of grapes. V. Explanation of GA effects on the induction of seedlessness and seedless berry development varying with cultivars Tohoku J. Agr. Res., 29, 111-119.

Ogasawara, S. (1985) Establishment of seedlessness berry production technique of grape by use of streptomycin preparation (SM). I. Induction of parthenocarpy in grape by application of SM. Bull. Hiroshima Fruit Tree Exp. Stn. 11, 39-49.

Ogasawara, S. and Hirata, K. (1985) Establishment of seedless berry production technique of grapes by use of streptomycin prepararion (SM). II. Stabilization of seedless berry production in Mucat bailey A by use of SM. Bull. Horoshima Fruit Tree Exp. Stn. 2, 51-58

Pal, R.N., Singh, R., Vu, V.K. and Munshi, S.K. (1977) Effect of 2, 4-D, GA3 and Cycocel, and Fruit Growth Pattern of Kinnow Mandarin. Indian Journal of Horticulture, 34, 4-7.

Pharis, R.P. and King. R.W. (1985) Gibberellins and reproductive development in seed plants. Аnпи. Rev. Plant Phys., 36, 517-568.

Reforgiato, R.G., Russo, G. and Recupero, S. (2005) New promising citrus triploid hybrids selected from crosses between monoembryonic diploid female and tetraploid male parents. Hort. Sci. 40, 516-520.

Rokaya, P.R., Baral, D.R., Gautam, D.M., Shrestha, A.K. and Paudyal, K.P. (2016) Effect of pre-harvest application of gibberellic acid on fruit quality and shelf life of mandarin (Citrus reticulata Blanco). American Journal of Plant Sciences, 7, 1033-1039. http://dx.doi.org/10.4236/ajps.2016.77098

Shiba, H. (1980) Practices to produce seedless berries in larg size berry cultivars ('Pionier' and 'Kyoho'). Agr. \& Hort. 55 (2), 294-298.

Shimizu, R. (1987) The effect of antibiotic application on the production of seedless grapes. Agr. \& Hort., 62 (7), $875-876$

Singh, A. K., Singh, R. and Mann, S.S. (2003) Effect of Plant Regulators and Nutrients on Fruit Set, Yield and Quality of Pear CV. Le-Conte. Indian Journal of Horticulture, 60, 34-39.

Takagi, T. (1980) Studies on the variation in flower types and its effect on seedlessness by GA in Muscat Bailey A grapes. Tech. Bull. 7, Dep. Hort. Fac. Agr. Shizouka Univ. 
U.S. Environmental Protection Agency. (1992) Registration Eligibility Document Facts. Streptomycin and Streptomycin Sulfate. USEPA. Washington, DC.

Vardi, A., Levin, I. and Carmi, N. (2008) Induction of Seedlessness in Citrus: From Classical Techniques to Emerging Biotechnological Approaches. J. Amer. Soc. Hort. Sci., 133 (1), 117-126.
Varoquaux, F., Blanvillain, R., Delseny, M. and Gallois, P. (2000) Less is better: new approaches for seedless fruit production. Trends Biotechnol., 18, 233-242. DOI: http:// dx.doi.org/10.1016/S0167-7799(00)01448-7

Zaghloul, A.E. (2004) Improving storage ability of Washington navel orange fruits under Kafr ElSheikh governorate conditions. Ph D. Thesis, Fac. Agric. Kafr El-Sheikh, Tanta Uni., Egypt.

(Received 29/5/2017; accepted $5 / 8 / 2017$ )

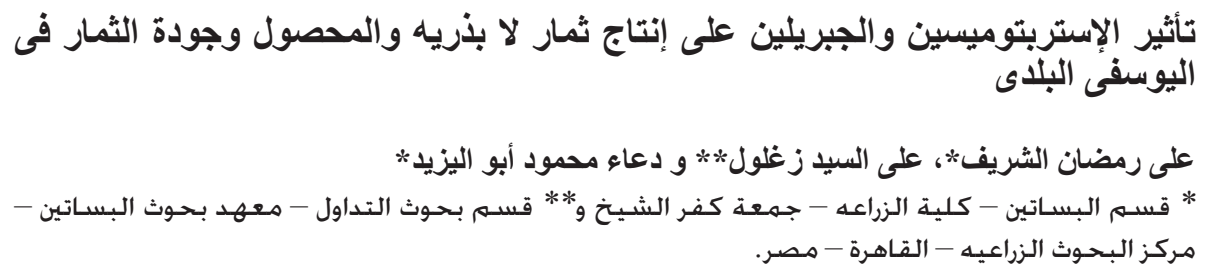

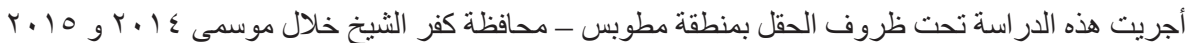

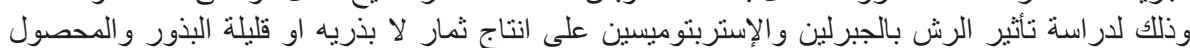

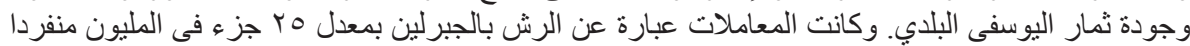

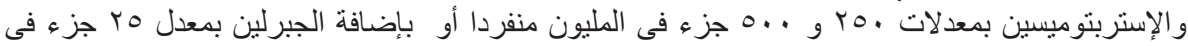

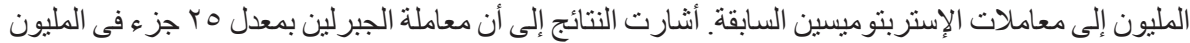

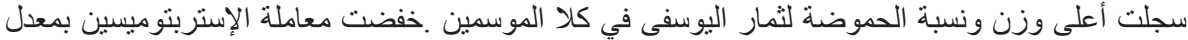

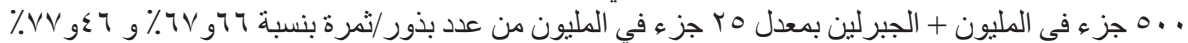

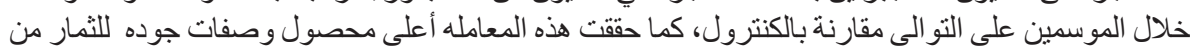

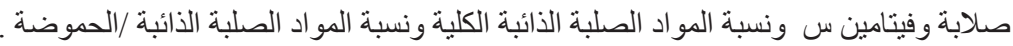

